\title{
Forms of care for children up to the age of three solutions preferred by parents (empirical research results)
}

\begin{abstract}
In Poland there is an ongoing social debate on preferences for various forms of care for children up to the age of three (young children) in government programs. Currently developed - thanks to implementation of the government program "Maluch" and "Maluch Plus" — a system of institutional forms of childcare is considered by conservative circles as overly favored, and the most beneficial - in their opinion - care provided by the mother at home, does not have adequate financial and image support in Polish family policy.

In a quantitative representative empirical study conducted in 2017 entitled "Mother, nanny or nursery? Opinions, needs and preferences of parents concerning the various forms of toddlers care", parents of young children, among others, defined their preferences and expectations regarding forms of care for a child up to the age of three and indicated - on the basis of their own experiences - the necessary forms of support for the care function of the family. The research results demonstrates that the most preferred
\end{abstract}

${ }^{1}$ Correspondence: Instytut Pracy i Spraw Socjalnych, ul. Bellottiego 3b, 01-022 Warszawa, Polska, author's email address: glogosz@op.pl 
option is care provided by the child's parents, but carried out jointly, interchangeably, by both parents. However, as this solution cannot be applied in every family situation, the respondents listed alternative instruments they considered necessary to provide adequate care to children up to the age of three, which included, among the others, developing a network of public nurseries.

The paper presents parents' preferred solutions and expected forms of supporting the care function of families with young children. A clear factor determining these choices and indications is the current situation of the family, and mainly the currently used form of care.

Key words: family policy, family care function, childcare, nurseries, institutional care, parental care, parental preferences

\section{Introduction}

In research papers and analytical publications, childcare issues are mainly present in three contexts:

- the labour market, where parents' caring responsibilities for young children are presented primarily in the context of reconciling family and professional roles (e.g., Chieregato, 2020; Sadowska-Snarska, 2007; Tomaszewska-Lipiec, 2014),

- gender equality, when childcare organization is recognized as an important instrument for shaping equal rights and opportunities in different areas of social and economic life (e.g., Charkiewicz \& Zachorowska-Mazurkiewicz, 2019; Kurowska et al., 2016, pp. 109-207; Szelewa, 2019a; Schwartz, 2019; Wódz \& Klimczak, 2020, pp. 9-32).

- different aspects of children's development, where they deal with theory and practice relating to the so-called Early Childhood Care \&Education (ECCE), which addresses the relationship between care and child development, where issues of a pedagogical, psychological, medical nature and issues relating to the material, social and cultural conditions of children's life and development predominate (e.g., Głogosz, 2008; Suter et al., 2019, pp. 307-309).

Both in the EU law and in the national law of the EU Member States, in strategies, plans or programs, each of these areas has its own separate regulations, goals and methods of their implementation, placing childcare in its proper context. However, it should be emphasized that these are not autonomous and separate contexts, as there are significant interdependencies between them. Therefore, neither the problems of childcare should be analysed only narrowly, taking into account only one area of its influence (Lohmann et al., 2016).

In Poland, issues related to care for young children (i.e., up to three years of age) are most often associated with the labour market and parents' professional activity ${ }^{2}$. This has

2 This is indicated by information on research subjects, socio-economic programs, studies, conferences, debates and other activities concerning the care of a young child. 
also been confirmed by empirical studies (Glogosz, 2018), of which the added value is their cross-country nature. They showed that parents of young children look at the care of their offspring also through the prism of their children's education, independence, acquisition of social competences, but also safety and health. Moreover, these issues in parents' opinions are often conditioned by their worldview, which is evident in opinions regarding the family model and the division of family responsibilities.

The paper presents selected issues concerning the forms of care for a young child preferred by parents having children up to three years of age and solutions supporting the family in this field in Poland. The aim of the following text is, among others, to indicate the importance of different contexts which determine the preferred forms of care of toddlers care by parents. The article is also a voice in the public debate on the directions expected by parents for the development of support for the care of a small child in the Polish family policy - a communication of their opinions and expectations.

\section{Institutional care of a young child - the main organizational principles}

The system of institutional (formal) care for toddlers in Poland was defined in the Act of 4 February 2011 on care for children aged up to three years ${ }^{3}$. In comparison with solutions in force in other EU countries, standards of this care in Poland are high (Głogosz, 2008). These restrictions, which are partly a legacy of the subordination of nurseries to the Ministry of Health, discouraged the creation of new facilities, especially so-called flexible ones, at the beginning of the first decade of this century (Muczyński $\& \dot{Z}$ ynel, 2007). Since 2011, in addition to nurseries, childcare for children up to the age of three may be provided by children's clubs and day care providers.

The principles of running a nursery (żtobki) and a children's club (kluby dziecięce) are defined in the Act of 6 March 2018 - Entrepreneurs' Law (Journal of Laws of 2019, item 1292). The institution must be entered in the register kept by the local government. This is possible when it meets certain standards that also apply to day care providers (opiekunowie dzienni).

The care in a nursery (local government, non-governmental or private institution) is provided for children from the age of 20 weeks to the end of the school year in which the child turns 3 or if it is impossible or difficult to cover the child with pre-school education - four years of age. However, according to statistics (GUS, 2019, p. 49), children up to one year of age in nurseries constitute only $1.5 \%$ of all children covered by such care; those aged one to two years constitute $39.2 \%$; and the largest number of children are two-three years old $-52.2 \%$. Children older than three years account for about $7 \%$ in nurseries.

The nurseries offer their services for 10 hours a day, unless parents request an extension of this time, which involves an additional fee. The tasks of the nursery are to guarantee the child proper care, upbringing and education appropriate to the child's age,

3 Consolidated text: Journal of Laws 2021, item 162. 
taking into consideration the child's psychomotor development and individual needs, and to provide food appropriate to the child's age (according to dietary standards).

There can be up to eight children per one caretaker and up to five children if there is a child in the group requiring special care (disabled or under one year of age). Moreover, a nursery attended by more than 12 children must employ at least one nurse or midwife. There are also standards concerning the number of rooms and their surface area, depending on the number of children and the length of their stay in the institution.

A children's club (local government, non-governmental or private) may take care of children from the age of one to the age of three or four, similarly to a nursery. Children can stay there for up to 10 hours a day, and at the parents' request this time can be extended. They share the tasks performed and the number of children per caretaker with nurseries. However, children's clubs are by definition smaller institutions than nurseries and may have no more than 30 places.

A day care provider is an appropriately trained natural person running a business activity concerning care for young children or a person employed by a local government unit, non-governmental organization, natural or legal persons on the basis of an employment contract or commission agreement. Such a person can take care of children of the same age as in nurseries and children's clubs. The care can be provided at home or in an apartment meeting the conditions ensuring safe care of children, the maximum number of which is five, and in the case of children in need of special care - a maximum of three children. Increasing this number of children is possible only conditionally - up to eight and up to five children respectively if two conditions are met jointly: consent of all parents and provision of a parent's assistance to the day care provider, and the premises' conditions allow for such a change. The day care provider's care is intended for a small number of children and is carried out in home conditions. The hours of service and the number of hours of care can be adjusted to the parents' working time.

For several years, there has been an open public debate about the forms of care preferred by parents of young children. Among the arguments, institutional care standards are also indicated. Therefore, it is worth noting that as of 1 January, 2018, some of these standards have been reduced or abolished. Among others, the obligation to have two rooms for the stay of children in nurseries has been eliminated, the working hours of children's clubs have been extended and the catalogue of entities that can create care institutions has been expanded.

Forms of institutional care also include care provided by a registered nanny. This is formal, but individual care of children of the same age as in the case of a stay in a nursery. The nanny is employed by the child's parents on the basis of the so-called nanny agreement, concluded in writing and reported to the Social Insurance Institution and the Tax Office. The social and health insurance premiums are paid either by the parents (when the remuneration is below $1 / 2$ of the minimum wage in the economy) or by the state budget (in other cases). 


\section{Care for the small child in Poland: the current state}

As of the end of 2019, there were 1 million 159 thousand children aged zero to two (i.e., up to three years of age) in Poland, including 792.1 thousand children aged one to two (GUS, 2019, Table 1). For references to the use of various forms of care for young children, the latter figure is important, as the vast majority of parents of new-born children provide care in person until the child reaches the age of one (ZUS, 2020, p. 15). This is possible thanks to the system of maternity, paternity, and parental leaves developed in 2013-2015, which taken together allow parents to provide personal care for their children for up to 52 weeks without interruption.

Statistics demonstrate that most children beyond the age of 1 are still mainly in parental care, which - to an unknown extent - is sometimes combined with care from other family members or non-professional caregivers. According to the Eurostat data (EU-SILC 2016 survey $^{4}$ ), about $40 \%$ of children up to the age of three in Poland use informal and private care. There are also 6.5 thousand registered nannies who care for children up to the age of three. Unfortunately, the total number of children under their care (hereafter referred to as non-parental care) is unknown. The offer of institutional care, i.e., in nurseries, children's clubs and day care providers, was used in 2019 by parents of 172.2 thousand children aged one or two, or $22.6 \%$ of the total number of children of this age (Sprawozdanie..., 2020, p. 13).

In 2002, during the EU summit in Barcelona, the so-called Barcelona targets were established, according to which $33 \%$ of children aged three and under should be covered by institutional care in each of the EU Member States by 2010. However, by 2011 only 6 EU countries had achieved this goal, and Poland was among the countries with the lowest rate in this respect - below 3\% (see also: Kurowska, 2015). Since March 2011, the aforementioned Act on the care of children aged up to three years has entered into force in Poland and, pursuant to it, the government program "Maluch" was implemented; since 2015 - "Maluch+." Local government units, natural persons, legal persons and organizational units without legal personality (including universities and their cooperating entities and employers) may apply for funding, in the form of a targeted grant from the state budget and for funds from the Labour Fund, which may — through a competition - obtain funds for the development and maintenance of nurseries, children's clubs and places with day carers. The development of institutional care for young children has also been financed from EU funds (the POWER program), which have been allocated mainly for training support, activities aimed at acquiring or improving competencies of entities creating and running institutions providing care for children up to three years of age, creating new care places, adjusting care places to the needs of children with disabilities and financing current costs related to the operation of these institutions (Sprawozdanie..., 2020, pp. 25-26).

42016 EU-SILC MODULE „Access to services” dostęp: https://ec.europa.eu/eurostat/documents/1012329/8088300/LC+221-18+EN+Module +2016+assessment.pdf/82b23b36-9e04-4905ab74-9a07f1223637. 
In 2011-2019, thanks to the programme, 56.5 thousand care places were established, of which as many as 45.2 thousand after 2015. In 2017, it was also made possible for entities other than municipal governments to apply for funding for the creation of new care places (and not only - as in previous editions - only the functioning of places). In 2018, the funds for the programme were increased to PLN 450 million and a guarantee was implemented for municipalities where no nurseries and children's clubs operate, concerning obtaining co-financing of up to $80 \%$ of investment costs. In 2019 , the subsidy amounts estimated for the creation of one place were increased and, as a result, the number of newly created places increased dynamically. While 8.1 thousand were created in 2017, about 16.3 thousand were created in 2018 and another 13 thousand places in 2019. However, there is still a significant demand that exceeds supply. Municipal governments and non-public institutions report a need for another 79.3 thousand places requested by parents (as of the end of 2019). Despite the significant improvement in this matter, there is still not a single nursery, children's club or day care provider in more than half of the municipalities (52\%) in Poland.

\section{Preferred forms of care for a toddler beneficial to the child (empirical findings)}

For several years now, Poland has been witnessing an open social debate on the directions of development as regards the care for children under the age of three. Its important elements include scientific discussions based on empirical research, public speeches of politicians, publications prepared by non-governmental organizations as well as debates in the media, including online parenting forums. The latter are valuable as they provide information directly from people affected by problems of providing care for a young child.

In 2019, a noticeable current in this debate were the voices of some politicians and NGOs associated with the conservative option ${ }^{5}$, pointing to the excessive attention and resources allocated in government programs to the development of institutional care and the underestimation of parental care. These contributions were accompanied, on the one hand, by strong criticism of nursery care as a solution that - in general - does not serve the well-being of children, while, on the other hand, the demand for further development of this form of care as an instrument to support the development of children and reconcile family and professional roles (Szelewa, 2019; Olek, 2019).

Unfortunately, these discussions have often used subjective opinions, individual cases and arguments mentioned in studies on the experience of other countries. The exchange

5 Elements of this debate included among others the exchange of opinions on nurseries between experts of Ordo Iuris and the Batory Foundation is the Open Letter on care for children under three years of age of 2018 (List otwarty..., 2018), addressed to the Prime Minister and parliamentarians, signed by fifty Polish psychiatrists, psychologists, pedagogues and lawyers or speeches in the Sejm (among others by Minister Barbara Socha and MP Jolanta Banach) on the implementation of "Maluch+" program in 2019. 
of views lacked the objective voice of parents who have their own experiences, thoughts and needs determined by the realities of their lives.

The information presented below is an excerpt from the results of the empirical research entitled "Mum, nanny or nursery? Opinions, needs and preferences of parents concerning the various forms of toddler care" from 20176 (Głogosz, 2018), that — by design - entered into this debate as a form of presenting the opinions of parents of small children.

\section{Methodology of empirical research}

The country-wide quantitative study entitled "Mum, nanny or nursery? Opinions, needs and preferences of parents concerning the various forms of toddler care" was carried out in 2017 and it was conducted in order to objectivize the information on parents' preferences regarding forms of care for a small child in Poland.

The research was to provide information to verify the following hypotheses:

1. The form of care for a child up to the age of three, preferred by parents, is care provided by the parent (verified positively).

2. When choosing a form of childcare, parents are mainly oriented towards its financial costs (verified negatively).

3. Parents expect such support in childcare which enables a gradual return/entry into the labour market (verified negatively).

The respondents (1,502 persons) included parents with at least one child up to three years of age, who personally took care of their toddlers (1st group - 501 persons), as well as those who used mainly ${ }^{7}$ care provided by others, including family members, nannies and non-professional babysitters (2nd group - 500 persons) and parents using nursery care (3rd group - 501 persons).

Data from the 2011 National Census and Central Statistics Office data on the demographic structure of the Polish population were used to select the sample (random quota). Respondents were selected to represent biological family types, number of dependent children, place of residence, education level, age and labour market status. The gender structure of respondents was the result of their independent decision on who would answer the interviewer's questions. The variation in indicators on the number of institutions for small children and the percentage of children in institutional care was also taken into account.

The research was conducted from 26 May to 30 June 2017, using the CAPI (computerassisted personal interviews) technique. An interview questionnaire was prepared for each of the 3 groups of respondents (closed questions, most with multiple choice and ranked answers, and the option to record an answer other than those listed in the cafeteria).

The questions of the interview questionnaire concerned, among others:

6 The research was carried out under an individual Grant of National Science Centre no 2015/17/D/HS5/02565 under the same title.

7 Groups of respondents were selected according to the criterion of dominant form of care. 
- the forms of early childhood care preferred by parents under different criteria

- reasons for choosing a form of care for toddlers

- the evaluation of different forms of care (their different components, accessibility and usefulness for the family)

- solutions (instruments, rules, new forms of support) expected by parents of small children.

The research concept and tools were subjected to substantive and methodological evaluation at scientific seminars.

The full research report is available on the website of the Institute of Labour and Social Affairs ${ }^{8}$

Apart from the basic part of the questionnaire, corresponding to the specificities of each of the three analysed forms of childcare, all of them had a common part containing information on the socio-demographic characteristics of the respondents, constituting the main independent variables (e.g., gender, age, type of family/family situation, place of residence, number and age of children, material situation and attitude to religion).

\section{Parents' opinions on nursery care (selected empirical findings)}

Respondents to the survey were asked, among other things, about the advantages and disadvantages of the various forms of care for a young child, including those they did not currently use. They answered questions concerning the reasons for choosing the current form of care. Moreover, they indicated which solutions they had used before (for older children) and which forms of care they would consider in the future (for subsequent children) and explained their answers. The research provided a wealth of information relevant to identifying the most important elements in childcare arrangements. These elements (e.g., child welfare, family income, availability of non-parental care ${ }^{9}$ ) influenced the preference for some solutions. The above information is the background for interpreting the answers to one of the most important questions asked to respondents (importantly: parents using different forms of care): which form of care is the most beneficial for a child aged up to three years? The most favoured evaluation of different forms of care in this context was care provided by both parents.

More than half of all respondents opted for this (see Table 1).

8 https://www.ipiss.com.pl/aktualnosci/mama-niania-czy-zlobek-opinie-potrzeby-i-preferencjerodzicow-dotyczace- form-opieki-nad-malym-dzieckiem-w-polsce-dorota-glo\%C2\%ADgosz

9 Accessibility in financial, spatial, qualitative and organisational terms. 
Table 1. Parents' preferences regarding the form of care that is most beneficial for the child under 3 years of age - by form of care currently applied, in \%

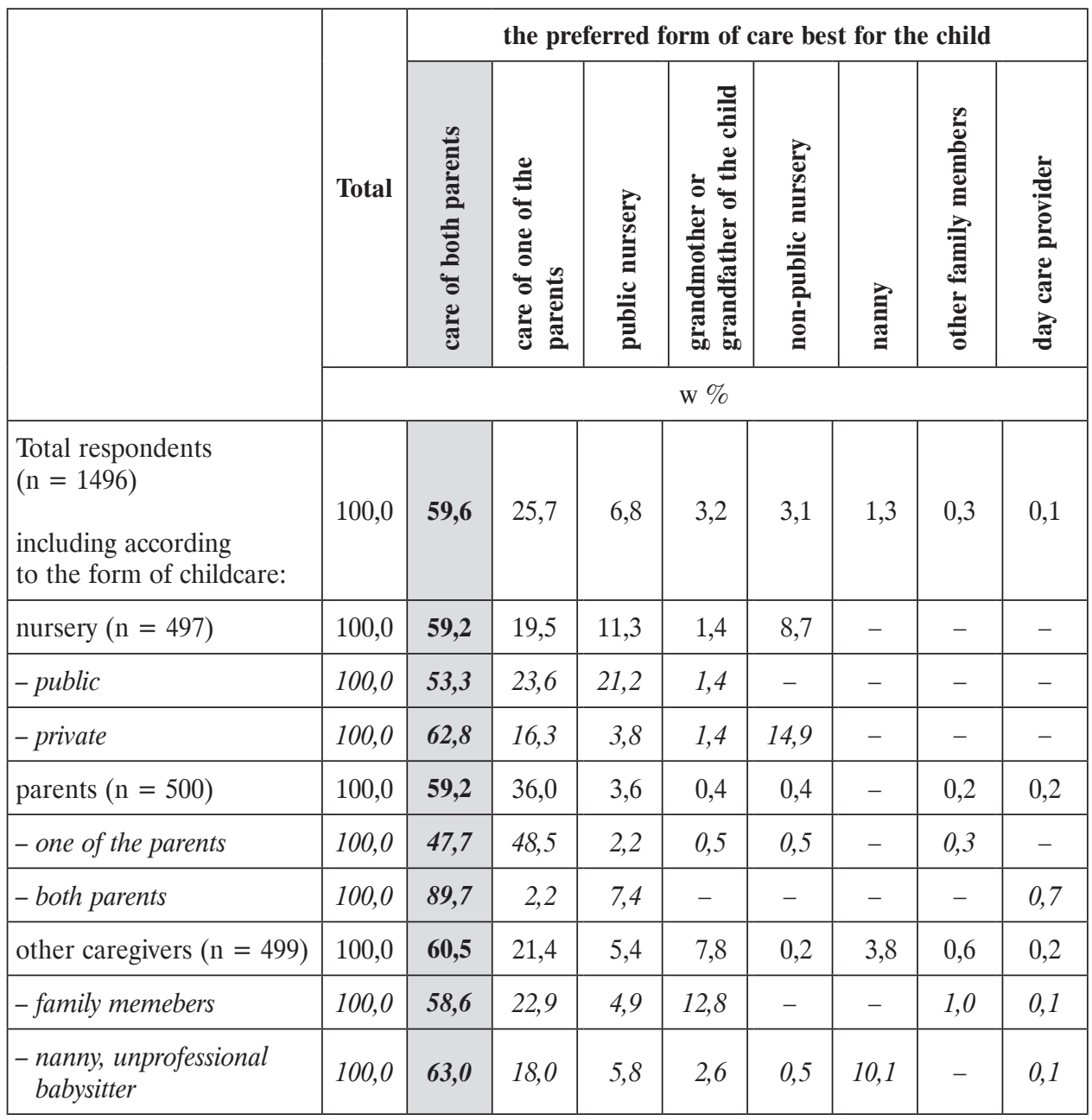

Source: Głogosz, 2018, pp. 92-93.

It is worth noting that childcare provided by both parents is considered the best solution for the child by nearly $90 \%$ of respondents who applied such a solution in practice.

The analysis of the relationship between selected socio-demographic characteristics of respondents and the preference for care provided by both parents ${ }^{10}$ shows that its supporters are:

- women more often than men,

10 Relationships were assessed on the basis of Spearman's rank correlations coefficient. Subsequent characteristics (gender, age, and others) are listed according to the correlation coefficient value, from the highest value (.97) to the lowest (.32). 
- older parents $(30+$ in the study) more often than younger ones,

- unmarried couples more often than those who are married,

- parents of at least 2 children more often than parents of only children,

- economically active people more often than inactive and unemployed,

- persons preferring partner division of duties in the family more often than persons from families preferring other role division,

- persons from families realizing disproportionately female family model more often than persons from families realizing other models,

- persons declaring themselves to be religious or non-religious more often than persons describing themselves as deeply religious.

A non-linear relationship was shown with regard to the respondents' level of education: parental care was more often preferred by respondents with primary, post-secondary and higher education than by those with vocational and secondary education.

Similarly, in the case of self-assessed financial situation of the household: respondents who assessed their financial condition as very good or very bad opted for care provided by both parents, while others did so less frequently.

To a large extent, the explanation for the above dependencies was found in the answers to questions concerning the evaluation of different forms of care for a young child, in which respondents pointed out their advantages and disadvantages as well as the reasons why they use or do not use a given solution.

Most participating parents, especially women, considered personal childcare to be the best option. For those who, by choice, personally cared for a young child jointly with the other parent (i.e., interchangeably), the preference for this solution confirms that they are satisfied with this option. Among those who used other ways of organising the care, the preference for involvement of both parents was an expression of their recognition of shared responsibility for the child, their appreciation of the father's role in raising a child, and their appreciation of the work they put into performing caregiving tasks. For some of the respondents, the involvement of both parents in care is also a necessary condition for implementing a partnership division of duties in the family, equalizing the chances for both the mother's and the father's involvement in non-family life (professional and social activity, own interests) with - considered to be the optimal solution - caring for the young child in person. On the other hand, in families experiencing financial problems, joint care of the child gave a better chance for generating income by both the child's father and mother.

Also, the parents' preference for other forms of childcare for a young child was related to the currently used solutions and their evaluation. Therefore, parents using nurseries were clearly more likely to consider nursery care preferable — for the sake of the child's well-being (those using public facilities pointed to public ones, those using private facilities to private ones), and those using nanny care were more likely than others to indicate that this was the care beneficial to the young child. Similar relationships were found for preferences for informal, non-professional care. 


\section{Parents' opinions on non-parental informal care}

An interesting result of this study is the identification of reasons for the limited preferences of parents of young children for non-parental informal care (see Table above). Such care, provided by family members and other non-professional caregivers, has a number of constraints in the parents' view, both in terms of supply and demand.

Firstly, the low scale of preference for such solutions is the result of a realistic assessment of access to care provided by family members (mainly grandparents). Most families with young children are single-family households, living separately, often at a considerable distance from the older generation. The barrier of spatial access means that parents of young children have limited opportunities to enlist the help of their family members. Second, a number of grandparents are unable or unwilling to take on the care of their grandchildren because they are still economically active (by choice or necessity). In addition, some of them are caring for their own parents or spouse. Third, some grandparents do not want to take care of their grandchildren (especially on a permanent, regular basis) because they want to dispose of their time themselves, relax, and devote to their own plans. In turn, when it comes to demand constraints, the research showed, among others, limited parental demand for such care due to reservations about its quality. More than $2 / 3$ of parents-respondents whose children were cared for by their family members (mainly grandparents) believe that this form of care provides the child with safety and contact with peers, but non-professional caregivers are not able to:

- take proper care of the child's intellectual development (they do not have the necessary knowledge, do not pay enough attention to stimulating the child's development through appropriately selected games, activities, methods of conduct),

- they do not care enough about making their children independent (they overdo it, unnecessarily help them in various activities),

- act consistently and teach their children rules (they spoil their children, also acting contrary to the rules of conduct declared by the parents). The upbringing patterns of parents and their adult children often differ significantly. These are behavioural standards, values, goals and attitudes of two different generations. This is why, among others, some parents prefer non-family care, where it is easier for them to enforce expected actions and behaviours from the caregiver, although in this solution they are more often concerned about the child's safety and - also - professional stimulation of their development.

\section{Expected family policy solutions to support parents in the care for children up to the age of three}

The research results quoted in this paper refer to a period when the Polish family policy was already functioning and undergoing reforms in the system of maternity, paternity and parental leaves. The government programme "Maluch" (then "Maluch+") was continued, which significantly increased the supply of various forms of institutional care for young 
children. Moreover, it became legal to employ nannies and obtain subsidies for insurance premiums paid on their salaries. Parents were also entitled to a child-raising benefit (the government programme "Family 500+"). In view of this quite rich variety of instruments (although nurseries were still not accessible for many parents), respondents were asked to indicate their own proposals of developing support in the care of young children, which — in their opinion - should be introduced or developed in Poland.

A synthesis of the proposals made by parents (see Figure 1) shows that they most often indicated as desirable in family policy the following:

1) further development of the leave system for parents and related benefits (47.3\% of respondents). Here, the need to allow parents to take personal care of their child after the parental leave has been used was pointed out. Currently, there is a possibility to take parental leave, which is not combined with a benefit, but only for people meeting a very low income criterion - with a low, in comparison with salaries (PLN 400), addition to the family budget due during parental leave.

2) development of the network of public nurseries (42.9\%). This solution was favoured mainly by those who used nurseries (almost $2 / 3$ of those who used public nurseries indicated the need for development of a network of such facilities), while it was much less frequently expected by parents taking care of their child personally (however, still $1 / 3$ mentioned it as necessary).

3) implementation of benefits for parents to finance forms of childcare of their choice (42.1\%). In the respondents' opinion, the child-rearing benefit " $500+$ " has fulfilled this role to a limited extent, although such, among others, justification for its introduction was indicated by representatives of the labour ministry (Parliamentary paper 216 of 2016 ${ }^{11}$ ). Respondents to the study were in favour of additionally introducing a care voucher - a form of non-cash settlement of payment for a service purchased by parents. The introduction of a benefit of this type was advocated by more than half of the respondents using nurseries and more than $60 \%$ of parents using non-parental care and $13 \%$ of parents taking care of their children themselves. These three directions of measures were among the most frequently indicated ones. Moreover, the most frequently indicated solutions (by at least $1 / 5$ of all respondents) included the following proposals:

4) introduction of tax allowances allowing for deduction (from tax or income) of childcare costs (this solution was indicated least frequently by parents who took care of their children themselves).

5) work organization making it easier to combine work and family care responsibilities (this solution was also most often pointed out by parents using nurseries but considered necessary by parents using other non-parental care solutions only slightly less often).

6) introduction of remuneration for childcare for non-working parents (the so-called family salary). This solution was most often favoured by respondents using non-parental care, especially care provided by family members. They also suggested that such a salary

11 Parliamentary Paper No. 216 - Government Bill on State Aid for Raising Children, https:// www.sejm.gov.pl/sejm8.nsf/druk.xsp?nr=216. 
should be available not only to parents, but also to other family members not working but taking care of children in the family (e.g., grandchildren).

The above three proposals are clearly related to disadvantages of various forms of care indicated by the respondents: cost barrier of non-parental institutional care (nannies, nonpublic nurseries), frequent cases of child illness in the nursery care and parents' problem with providing care for them at that time as well as cases when grandparents do not provide childcare because they are still of working age and want to continue working professionally.

Respondents using nurseries indicated the greatest variety of activities, considering them necessary to provide proper care for young children. On the other hand, characteristic of non-parental care users, apart from the preferences indicated above, were indications aimed at increasing the availability of nannies. This group of parents, seeing the need to increase both the quantitative availability of this form of care, as well as the qualitative availability of these services, pointed to the necessary development of a network of professional care agencies, preparing professional staff, certifying services and guaranteeing the quality of care. In addition to the high cost of care provided by nannies, parents pointed to insufficient professionalization of these services, and thus the lack of a guarantee of safe care for the child (less frequently, but also indicated that the care provided by nannies is not professional enough to properly stimulate the child's development).

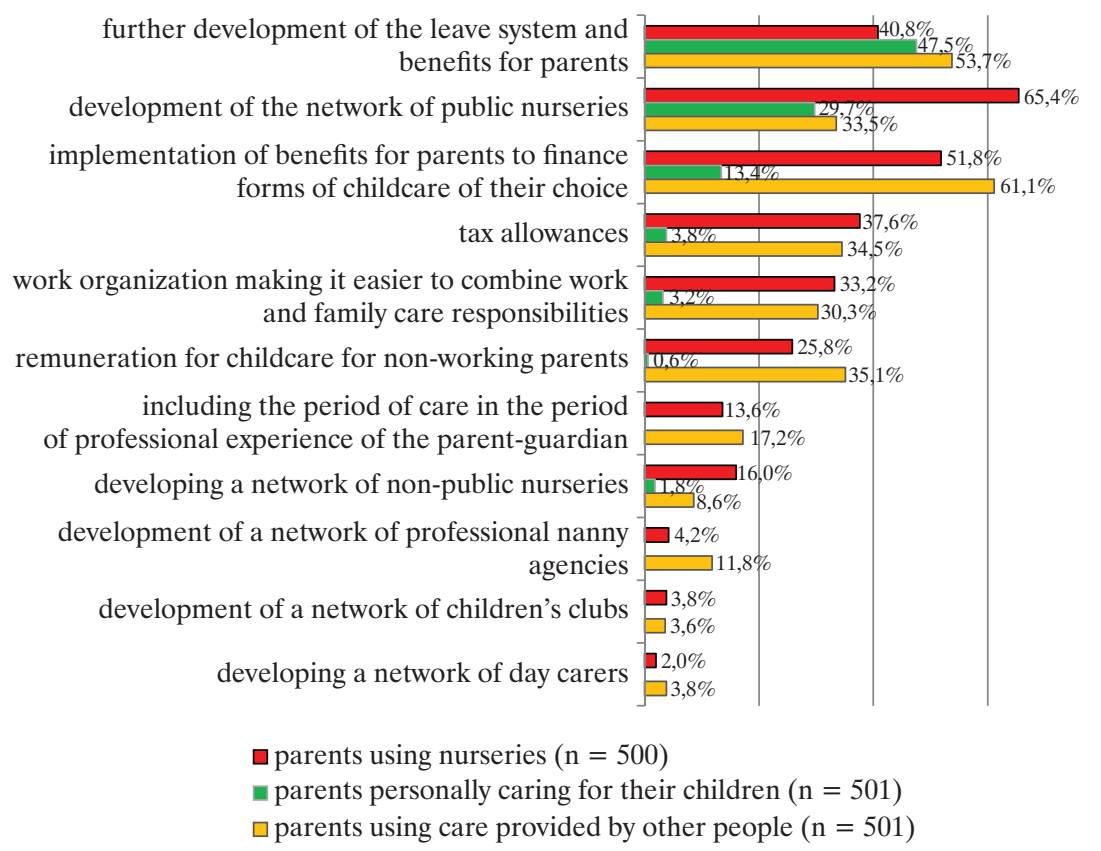

Fig. 1. Solutions in the field of care for a young child that should be developed and/or implemented in Poland according to currently used forms of care — parents' indications (in \%)

Source: Głogosz, 2018, p. 96. 
Tax benefits, remuneration for the care of own child or grandchild as well as organization of work in a way that is helpful in caring for young child constitute the proposals for measures supporting the family's care functions that focus on financial issues. Therefore, it seems obvious that they were opted for more often by parents assessing the situation of their households as worse than average, and significantly less often by those assessing it as average or better, but also more often by respondents who are economically active or temporarily unemployed (e.g., on leave) than economically inactive.

The quoted studies also show that parents of young children rarely consider as necessary the development of "intimate" institutional care solutions (children's clubs, day care providers), which were established as an alternative to nursery care, devoid of its disadvantages. Respondents appreciated such features of clubs and day care providers as small groups of children, proximity to home, short and flexible care time, possible significant parental influence on the form and scope of care, but relatively rarely indicated the need to develop these forms (see Figure 1). The research results presented here do not provide an answer as to the reasons for such a state of affairs. However, it can be assumed that children's clubs and day care providers are forms of care considered by parents as valuable and needed solutions, but only complementary, supporting mainly parental care as the primary one.

\section{Conclusion}

The analysis and discussion of the problems concerning the care of young children requires taking into account the different contexts and objectives related to the creation of social policy, especially the government and local governments' family policy in this area. All arguments, postulates, proposals for action, solutions preferred or deprecated should take into account both their current and future social and economic effects and the diverse environmental conditions of the functioning of these ideas.

Parents' preferences for childcare facilities for children up to three years of age and solutions to support the childcare function of families, and the reasons for these preferences, indicate that a significant proportion of respondents perceive both current and prospective consequences of their choices for the child's well-being. What is important for them is to provide the child with the most favourable conditions for physical and mental development. This criterion (the child's well-being) is - in their opinion - met to an optimal degree by care provided by both parents. A real support for such a solution should be the development of leave systems for the time necessary for parental care ${ }^{12}$. However, they expect - especially women -mothers - that the performance of their caring functions will be appreciated both by the other parent as well as "by the state" and its support instruments which allow for other forms of activity (e.g., part-time or flexibly organized work which can be combined with caring, social activity, developing interests).

12 The view that until a child is three years old, care should be provided by the mother is widely accepted in Polish society. This is confirmed by the results of scientific studies and public opinion polls, e.g., CBOS, 2018, p. 5; Zych et al., pp. 69-93 and 132-133. 
The point is that caring for a child should not consume all the caregiver's time and that care should be valued in real terms. It is also important that the whole family be provided with economic security (the possibility for both parents to earn income from work or from benefits for caregivers in lieu of wages).

The presented research clearly indicated one form of care - the care given in person by both parents - as the most appropriate, but a significant part of the postulated supporting solutions had the nature of instruments allowing for parents' autonomous decisions concerning the choice in this regard (e.g. a voucher for financing the chosen form of care). A significant group of parents stressed the need for the development of network of public nurseries. Interestingly, other forms of non-parental care - such as paid nannies and children's clubs - were not indicated, among the desired instruments that should be supported. It is also worth noting that the proposals which indicate that the quality aspect of care, its professionalization and the possibility of using forms which supplement parental care are also important for parents. On the other hand, it should be noted with some concern that the solutions regarding crediting periods of childcare with the length of service, i.e., giving the caregivers a chance for a future pension from the social insurance, have met with little interest. On this basis it can be concluded that the awareness of the consequences of long-term professional inactivity and lack of social insurance is rather low among parents.

Some of the suggested instruments are already functioning in the Polish family policy, although it is not always emphasized that they are aimed at supporting the caretaking function in a family (e.g., the child-rearing benefit 500 plus, which has been programmed as an instrument of demographic policy and an instrument for fighting child poverty).

As every empirical study, this one also has its limitations. The respondents were asked generally, about the preferred form of care for children up to the age of three. We cannot rule out the possibility that the indicated most preferred form of care would be different if parents were asked separately which form of care they would prefer for a one-year-old and for a two- or three-year-old. This makes an avenue for future research.

Presented in the paper information from empirical research provides a quite broad overview of preferences and proposals for solutions concerning care of a young child in Poland. What is important is the fact that they were expressed by people who are directly affected by the way of organizing and supporting the care function in the family - i.e. parents of children aged three or less. Data of this nature should constitute the main premise for shaping family policy solutions in its broad sense (Balcerzak-Paradowska, 2004).

\section{References}

Balcerzak-Paradowska, B. (2004). Rodzina i polityka rodzinna na przetomie wieków. Przemiany, zagrożenia, potrzeba dziatań. Instytut Pracy i Spraw Socjalnych.

CBOS. (2018). Kobiety i mężczyźni w domu. Komunikat z badań nr 127. Centrum Badania Opinii Społecznej. 
Charkiewicz, E. \& Zachorowska-Mazurkiewicz, A. (ed.). (2019). Gender i ekonomia opieki, Fundacja Tomka Byry. Ekologia i Sztuka.

Chieregato, E. (2020). A Work-Life Balance for All? Assessing the Inclusiveness of EU Directive 2019/1158 (December 12, 2019). International Journal of Comparative Labour Law and Industrial Relations, 36(1), 59-80.

Głogosz, D. (2008). Organizacja i funkcjonowanie pozarodzinnej opieki nad dziećmi w krajach UE — kierunki zmian. In C. Sadowska-Snarska (ed.), Kierunki zmian w systemie instytucjonalnej opieki nad dzieckiem w Polsce. Wyższa Szkoła Ekonomiczna w Białymstoku.

Głogosz, D. (2018). Mama, niania czy żłobek? Preferencje opinie i potrzeby rodziców dotyczace różnych form opieki nad małym dzieckiem. https://www.ipiss.com.pl/aktualnosci/ mama-niania-czy-zlobek-opinie-potrzeby-i-preferencje-rodzicow-dotyczace-formopieki-nad-malym-dzieckiem-w-polsce-dorota-glo\%c2\%adgosz.

GUS. (2019). Ludność. Stan i struktura ludności oraz ruch naturalny w przekroju terytorialnym (stan w dniu 31.12.2019). https://stat.gov.pl/obszary-tematyczne/ludnosc/ ludnosc/ludnosc-stan-i-struktura-ludnosci-oraz-ruch-naturalny-w-przekroju-terytorialnymstan-w-dniu-31-12-2019,6,28.html.

Kurowska, A. (2015). Changes in early childcare services in Poland before and after the implementation of the "nurseries" act. Problemy Polityki Spotecznej. Studia i Dyskusje, 30(3), 119-139.

Kurowska, A., Pieliński, B., Szarfenberg, R. \& Wójtewicz, A. (ed.). (2016). Perspektywa gender w polityce spotecznej. Wydawnictwo Naukowe Uniwersytetu Mikołaja Kopernika w Toruniu.

List otwarty w sprawie opieki nad dziećmi do lat 3. listopad 2018. https://ekai.pl/dokumenty/list-otwarty-w-sprawie-opieki-nad-dziecmi-do-lat-3/

Lohmann, H. \& Zagel, H. (2016). Family policy in comparative perspective: The concepts and measurement of familization and defamilization. Journal of European Social Policy, 26(1), 48-65. https://doi.org/10.1177/0958928715621712.

Muczyński, M. \& Żynel, M. (2007). Elastyczne przedszkole i żłobek — model placówki samorządowej dostosowanej do potrzeb rodziców. In C. Sadowska-Snarska, System instytucjonalnej opieki nad dzieckiem $w$ aspekcie godzenia życia zawodowego z rodzinnym. Wyższa Szkoła Ekonomiczna w Białymstoku.

Olek, M. (2019). W drodze do lepszego modelu opieki nad małymi dziećmi. Fundacja Instytut na rzecz Kultury Prawnej Ordo Iuris.

Sadowska-Snarska, C. (2007). System instytucjonalnej opieki nad dzieckiem w aspekcie godzenia życia zawodowego z rodzinnym, Wyższa Szkoła Ekonomiczna w Białymstoku. Schwartz, L. (2019). Feminism and the Servant Problem. Cambridge University Press.

Sprawozdanie... (2020). Sprawozdanie Rady Ministrów z realizacji ustawy z dnia 4 lutego 2011 r. o opiece nad dziećmi w wieku do lat 3 w 2019 r. Druk nr 694. Sejm Rzeczpospolitej Polskiej.

Suter, L. E., Smith, E., Denman, B. D. (2019). The SAGE Handbook of Comparative Studies in Education. Sage. 
Szelewa, D. (2019). Polityka opieki nad matym dzieckiem: ustugi edukacyjno-opiekuńcze a instrumenty pieniężne. Fundacja im. Stefana Batorego.

Szelewa, D. (2019a). Invention-Institutionalization-Implementation: The Origins of Childcare Policies in Poland. Social Politics: International Studies in Gender, State \& Society, 26(1), 139-163. https://doi.org/10.1093/sp/jxy009.

Tomaszewska-Lipiec, R. (ed.). (2014). Relacje praca - zycie pozazawodowe: droga do zrównoważonego rozwoju jednostki. Uniwersytet Kazimierza Wielkiego w Bydgoszczy.

Wódz, K. \& Klimczak, J. (2020). Genderowa perspektywa w polityce społecznej i w pracy socjalnej. Próba rekonstrukcji głównych założeń i ich implikacji dla praktyki. Przegląd Socjologiczny, 69(2), 9-32.

ZUS. (2020). Informacja o świadczeniach pieniężnych z funduszu ubezpieczeń społecznych oraz o niektórych świadczeniach z zabezpieczenia społecznego, II kwartał. Okres I-VI 2020 r. Zakład Ubezpieczeń Społecznych.

Zych, T., Dobrowolska, K., Szczypiński, O. (ed.). (2015). Jakiej polityki rodzinnej potrzebuje Polska? Instytut na Rzecz Kultury Prawnej Ordo Iuris

\section{Legal acts}

Act of 6 March 2018 - Entrepreneurs' Law, Journal of Laws 2021, item 162 Consolidated text 